\title{
The Neirabian Community in Babylonia
}

Until now, this study has focused on Judean communities in Babylonia. It has to be emphasised, however, that Judeans were but one of numerous population groups deported to Babylonia in the late seventh and early sixth centuries. A case study of the Neirabian community in Babylonia allows us to control the research results obtained so far and determine whether they can be applied to deported communities in Babylonia in general. The Neirabians originated from Neirab, Syria, whence they were deported to Babylonia and resettled in the village of Neirab. They were integrated into the land-for-service sector of the agrarian economy, and the documents pertaining to them closely resemble the transactions from Yāhūdu and its surroundings. However, the cuneiform tablets pertaining to the Neirabians were discovered in Neirab, Syria. This indicates that a number of Neirabians returned to their ancestral hometown in the early Persian period.

\subsection{Neirab of Syria and Neirab of Babylonia}

The town of Neirab, located some ten kilometres south-east of Aleppo, has retained its ancient name across the millennia and can still be found on maps of modern Syria. ${ }^{1200}$ This Aramean town is known from Neo-Assyrian royal correspondence and royal inscriptions, ${ }^{1201}$ and its site was partly excavated in 1926-1927 after a stone sarcophagus and two funerary stelae were discovered during construction work in the late nineteenth century. ${ }^{1202}$ The Aramaic stelae commemorate two priests of Sahr at Neirab, Sîn-zēr-ibni and Si'gabbar, the latter of whom is also mentioned in a Neo-Assyrian letter from the late eighth

1200 Röllig 1998-2001, 215; Tolini 2015, 58.

1201 The town is mentioned in SAA 1 189; SAA 6 326; RINAP 1, Tiglath-pileser III 43: ii 3. The first document, a letter probably sent by the governor of Harran to Sargon II, refers to

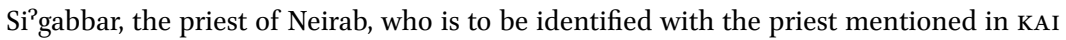
226 (see Parpola 1985; PNA 2/II, 858-859). The second document is a sale of an agricultural holding near the town of Neirab in the reign of Assurbanipal (see PNA 3/1, 10381041). The last document, a royal inscription of Tiglath-pileser III, lists Neirab among the towns which were under Assyrian rule in the territory of Bìt-Agūsi (see also Röllig 19982001, 215).

1202 Barrois 1927; Carrière and Barrois 1927; Abel and Barrois 1928. 
century. ${ }^{1203}$ Even though no temple was found during the excavations of the site, references to the priests of Sahr suggest that the West Semitic moon god had a shrine in the city. ${ }^{1204}$ The excavations revealed an ancient cemetery that was in use from the late Neo-Assyrian until Persian period; however, the tell was only partially excavated, and the living and public quarters of the city remain unstudied. ${ }^{1205}$ Due to the incomplete excavations and brief excavation reports, we know relatively little about the site.

Judging by the stelae of the two priests and stone sarcophagi discovered at the site, at least a part of the people buried in the necropolis of Neirab belonged to the higher strata of the local community. This needs to be taken into account when evaluating the find of 27 Neo-Babylonian cuneiform tablets from the cemetery: 25 of them were found next to a scarab and human remains in 1926 and two more tablets were discovered in an unspecified archaeological context a year later. In addition, a piece of pottery with some Assyrian cuneiform signs was discovered in $1927 .{ }^{1206}$ In contrast to the stelae and stone sarcophagi found at the site, the tomb next to the 25 tablets was simple; however, the connection between the tomb and the tablets remains obscure. ${ }^{1207}$ The tablets were published by Édouard Dhorme in $1928,{ }^{1208}$ but due to the advancements in the field during the past century, a new edition of the tablets is a desideratum. Gauthier Tolini has announced his plans to republish the texts held in Jerusalem, but the tablets in Aleppo would not be included in the new edition. ${ }^{1209}$

In his editio princeps, Dhorme declared that the tablets were written in the period extending from the reign of Nebuchadnezzar II to the reign of Darius I. ${ }^{1210}$ Some tablets were drafted in Neirab, others in Babylon, Ammat (which he identified as Hamath), Hīt, and Bīt-dayyān-Adad (which he located near Aleppo,

1203 The stelae, first published in Clermont-Ganneau 1897 and subsequently edited as KAI 225 and 226, are discussed in Yun 2006; Niehr 2014, 190-192, pls. XVII, XIX; both with bibliographies. For the Neo-Assyrian letter, see the footnote above.

1204 Niehr 2010, 255.

1205 On the dating and the importance of the cemetery, see Röllig 1998-2001, 215; Nunn 2000, 393, 436-439; Niehr 2010, 253-258; 2014, 192. Also see the excavation reports in Barrois 1927; Carrière and Barrois 1927; Abel and Barrois 1928.

1206 Barrois 1927, 263; Carrière and Barrois 1927, 138; Abel and Barrois 1928, 318.

1207 Oelsner $(1989,72)$ rightly describes the burial as a simple one. He also suggests that the tablets were found in the foundations of a house, but the excavation report seems to suggest a graveyard context.

1208 Dhorme 1928. Other important studies are Fales 1973; Eph'al 1978; Oelsner 1989; Cagni 1990; Timm 1995; Cussini 2000; Tolini 2014, 2015.

1209 Tolini 2015, $59+$ n. 8 .

1210 Dhorme $1928,53-55$. 
the cult centre of Hadad). Dhorme noticed that the descendants of a man called Nusku-gabbē had a prominent role in the documents, but since his primary aim was to publish the tablets, he did not devote much space to a discussion of their contents.

Dhorme's chronology was questioned by Albrecht Goetze, who proposed that the time span of the archive should be shortened from Nebuchadnezzar II Darius I to Neriglissar - Darius I. According to him, the concentration of the documents in the reign of Nabonidus makes it problematic to assign nos. 1 and $2^{1211}$ to the reign of Nebuchadnezzar II. He argues that the short reign of Nebuchadnezzar IV is more fitting. ${ }^{1212}$ The case of no. 1 (4-VI-1 Nbk) is a clear one, because dating the tablet to the reign of Nebuchadnezzar IV shortens the timespan of the archive by several decades. No. 2 does not preserve the exact regnal year, and dating it to the late reign of Nebuchadnezzar II would not expand the temporal scope of the archive too much. ${ }^{1213}$ That would also shorten the active period of a certain Nuhsāya/Nusku-gabbē from 35 years (o Nbn - 1 Nbk IV) to circa 25 years (late Nbk II to $16 \mathrm{Nbn}$ ). ${ }^{1214}$ However, the activity of a certain Nargia/Hananaia in $3 \mathrm{Nbn}-1$ Camb (nos. 6, 11, 12, and 19) and the attestation of his son Hidirāya in no. 2 supports the dating of the tablet later, because the son was hardly active before his father. ${ }^{1215}$ Accordingly, it is sensible to date no. 2 to the reign of Nebuchadnezzar IV as well: Nuhsāya's active period of 35 years is not unprecedented, Hidirāya was likely active only after his father, and the timespan of the archive is shortened by some years.

Dhorme's natural assumption was that the place name Neirab mentioned in the tablets was to be identified as the place where the tablets were excavated. This view held until 1978, when Israel Eph'al proposed that the Neirab mentioned in the cuneiform tablets should be located in Babylonia instead of Syria. ${ }^{216} \mathrm{Eph}^{\varsigma}$ al argued that various problems occur when one tries to follow Dhorme's suggestion that the toponyms mentioned in the archive should primarily be located in Syria. Julius Lewy had already earlier criticised Dhorme's identification of Ammat (Am-mat) with the Syrian city of Hamath because the place name Hamath is normally written in Assyrian and Babylonian sources as Ha-ma-(a)-tu or A-ma-tu. ${ }^{1217}$

\footnotetext{
1211 The numbering of the texts follows Dhorme 1928.

1212 Goetze 1944, 45 n. 22. He is followed by Eph'al 1978, 84; Tolini 2015, $5^{8}+$ n. 2.

1213 Oelsner 1989, 68-69.

1214 His earliest certain attestation is in $24-\mathrm{VI}-\mathrm{o}$ Nbn and his last certain attestation in 1-X-16 Nbn.

1215 Tolini 2015, 71-72+ n. 54 .

1216 Eph'al 1978, 84-87.

1217 Lewy 1943-1944, 431-433; 1950-1951, 373-374 + n. 52. See also Eph`al 1978, 85.
} 
Eph'al noticed that some persons are present in several localities attested in the texts, which indicates that the places were not far away from each other. ${ }^{1218}$ In one case, a scribe and witness appear in two documents written on the second and fourth days of the seventh month in the tenth year of Nabonidus: the first document (no. 11) in Bīt-dayyān-Adad and the second (no. 12) in Ammat. If the former town was located near Aleppo and the latter is identical with Hamath, the two persons travelled a distance of 150 kilometres in a couple of days. Moreover, Hìt and Babylon are both far away from the Syrian town of Neirab. In addition, one tablet (no. 17) was written in a place called Ālu ša Nērebāya ša ina muhhi nāru ša Bēl-ab-ușur ('the Town of the Neirabians which is located on the Bēl-ab-ușur canal'). There were not, however, any canals in the vicinity of Neirab in Syria. Finally, Eph ${ }^{\mathrm{S}}$ al argued that it is peculiar to find a dossier of Babylonian cuneiform tablets in the Aramaic-speaking region in Syria, where people would probably have used their mother tongue to write such documents. All the scribes in the archive bore Babylonian names.

These observations led $\mathrm{Eph}^{\complement}$ al to suggest that the Neirab attested in the clay tablets should be located in Babylonia instead of Syria. This would explain why the tablets are similar to Babylonian legal documents from the sixth century and why canals are mentioned in the texts. In fact, the town of Ammat ${ }^{1219}$ and the Bēl-ab-ușur canal are known to have existed in the Nippur region. ${ }^{1220}$ What is most important, the phenomenon of twin towns is widely attested in the countryside around Nippur. ${ }^{1221}$ According to Eph ${ }^{\varsigma}$ al, the Neirabians lived in Babylonia as deportees, but some of them returned to their ancestral hometown in Syria in the early Persian period and took some of their cuneiform documents along. That is the reason why the tablets were excavated from Neirab, Syria. Eph ${ }^{\Upsilon} a l ' s$ theory has aroused criticism by Stephanie M. Dalley and Luigi Cagni, ${ }^{1222}$ but most scholars accept his view. ${ }^{1223}$ As there seems to be no other way to explain the contents of the archive and its find-spot in Syria, $\mathrm{Eph}^{\text {`al's }}$ thesis is followed here.

Accordingly, the village of Neirab is to be seen as a settlement of Neirabian deportees in the Babylonian countryside. The deportation took place during the campaigns of Nabopolassar or Nebuchadnezzar II, and, following a wellknown practice, the deportees were settled in a community according to their

\footnotetext{
1218 Eph $^{\varsigma}$ al $1978,84-87$.

1219 BE 840.

1220 BE 9 65; PBS 2/1 104.

1221 Dandamayev 2004.

1222 Dalley 1984; Cagni 1990.

1223 Joannès 1982b, 35; Oelsner 1989 (with some caution); Timm 1995; Dandamayev 2004, 141142; Pearce 2006, 408; Beaulieu 2007, 201-202; and, most recently, Tolini 2015, 60-66.
} 
place of origin and their settlement was named Neirab or 'the Town of the Neirabians on the Bēl-ab-ușur canal.'.1224 The usage of these two different place names closely resembles the case of Yāhūdu and Āl-Yāhūdāya. Some of the Neirabians returned to their ancestral hometown in Syria in the early Persian period, taking a dossier of cuneiform tablets along with them. Because the tablets were unearthed in an ancient cemetery, it is likely that they were buried together with a deceased returnee from Babylonia. The deceased probably enjoyed some social standing in the community because he was buried in the same necropolis with local priests.

\subsection{The Archive and Its Socio-Economic Context}

\subsubsection{The Protagonists of the Texts}

The protagonists of the Neirab texts are descendants of a certain Nusku-gabbē. The central figures include his two sons, Nuhsāya and Nusku-killanni, and the latter's son Nusku-iddin, who was perhaps the last owner of the archive. ${ }^{1225}$ Other sons of Nusku-gabbē - Sîn-uballit, Manniya, and Sîn-ab-ușur - appear in the archive sporadically. ${ }^{1226}$ The sons and grandsons of a certain İn-Nusku are also important, because several members of the family are present in eight or nine documents of the archive (nos. $7,13(?), 14 \| 24,15,17-18,21$, and 27$).{ }^{1227} \mathrm{~A}$ longstanding business relationship or a kinship tie is the most likely reason for the strong presence of the İn-Nusku family in the archive. In the same manner, Nargia/Hananaia was probably a relative or business partner of the Nuskugabbē family; he is attested in nos. 6, 11-12, and 19, and his son Hidirāya in no. 2. ${ }^{1228}$

A peculiar feature of the archive is the abundance of personal names connected with the lunar cult, and the deities Nusku and Sahr/Sîn have a prominent role among the deities attested as theophoric elements in personal names. ${ }^{1229}$ This phenomenon is to be connected to the geographic origin of the archive holders: the lunar cult was of great importance in northern Syria in the

\footnotetext{
1224 The place name is written in two different ways. The shorter form is attested in nos. 19, 23, and 26 , and the longer form in no. 17 .

1225 Nuhsāya: nos. 2, 3(?), 4-6, 10-13, 17-18; Nusku-killanni: nos. 7, 8||9, 10, 14||24, 15-16; and Nusku-iddin: 1, 18-19, 27(?). See Fales 1973, 132-137; Tolini 2015, 67-70.

1226 Sîn-uballiț: no. 4; Manniya: nos. 7, 8||9; Sîn-ab-uṣur: no. 8\||9.

1227 For this family, see Fales 1973, 138-141; Tolini 2015, 72-73.

1228 For the identification of Nargia and Hidirāya, see Tolini 2015, 71.

1229 Tolini 2015, 67-76. See also Zadok 2003, 556-558.
} 
mid-first millennium. ${ }^{1230}$ This does not apply only to Harran, the cultic centre of Sîn, but also to Neirab, as the two stelae of the priests of Sahr demonstrate. Moreover, text no. 26 of the Neirab archive refers to Sîn of Neirab, which further stresses the importance of the lunar cult for the Neirabians. In the Neirab archive, the theophoric elements Sîn and Nusku in West Semitic names can be used as a criterion to identify people of Neirabian origin. ${ }^{1231}$ The concentration of Sîn and Nusku names in the Neirabian texts can be compared with the concentration of Yahwistic names in Yāhūdu.

\subsubsection{Promissory Notes for Barley}

The documents of the archive are mainly promissory notes for barley and silver, accompanied by some property and family documents. On average, the size of silver loans is relatively smaller than those of barley: eight out of nine promissory notes for silver range between 2.25 and 9.5 shekels, with only one broken document referring to a loan of at least one mina. On the other hand, the amounts of eight barley loans range between 6.66 and $40+k u r r u$, with the average being over 18 kurru. Only three promissory notes (nos. 4-6) hold interest.

The eight promissory notes for barley $(3-6,10,15,17,18)$ appear to fit a certain pattern. As noticed by Tolini, seven out of the eight debts were to be paid back in the second month of the year, at the time of barley harvest. ${ }^{1232}$ Moreover, except for nos. 4 and $5,{ }^{1233}$ all promissory notes were issued at the turn of the year, which leads Tolini to suggest that some of the debts were taken to support the Neirabian community during the time of food shortage before the new harvest. Since the descendants of Nusku-gabbē are debtors in all documents, but the amounts of barley are too large for the consumption of a single family, Tolini suggests that the family played a leading role in the community to which it distributed the borrowed barley. ${ }^{1234}$ However, two additional features of the documents and their socio-economic setting have to be taken into account.

First, five promissory notes can be connected to the royal administration. The names of three creditors - Šar-gabbi-lē’i/Ilqataru, Šar-bēlšunu/[...]-tarra, and Iltammeš-ili/Šar-gabbi-lēêi $(4,5,10)$ - betray such a link. One creditor,

\footnotetext{
1230 Lipiński 2000, 620-623.

1231 For a more thorough methodological discussion, see Tolini 2015, 70.

1232 Tolini 2015,81 . No. 7 is damaged and the term of the loan is illegible.

1233 No. 4 is written in 24 -VI-o Nbn. No. 5 is damaged and the month of issue is illegible.

1234 Tolini 2015, 77-83, 86. But cf. Fales (1973, 137-142), who perceives the descendants of Nusku-gabbē as businessmen. According to him, the preserved tablets constitute only a part of their archive, not including the promissory notes issued by the family.
} 
Adad-[...]/Harimma ${ }^{2}$, has the title of royal merchant. ${ }^{1235}$ The West Semitic names of Ilqataru, Iltammeš-ili, and Harimma? yet again emphasise the international character of the royal administration in the long sixth century. ${ }^{1236} \mathrm{In}$ no. 6, the leased barley originates from the royal property (níg.ga lugal). The strong involvement of the royal administration in the promissory notes is noteworthy, and it indicates that the crown had substantial interests in the agricultural activities pursued in Neirab.

Second, two promissory notes exhibit a more complicated administrative structure. In no. 6, barley from the royal property is owed to PN/Itti-Šamaš[balāțu?], at the disposal of a certain Ardiya, and owed by Nuhsāya/Nuskugabbē. In promissory note no. 18, three sons of Nusku-gabbē owe a sūtu rent of 6;3.2 kurru of barley. The rent is due from a landholding, the management of which involved three different persons; unfortunately, their names are broken. The texts suggest that the Neirabian community was part of a complex hierarchy of land tenure and their position was close to the lowest rung of the ladder. Text no. 18 could be related to lands in private ownership, ${ }^{1237}$ but text no. 6 betrays the royal ownership of the land under tenure. Moreover, royal involvement in the affairs of the Neirabians is corroborated by no. $8 \| 9$, preserved in two copies. In this text, Manniya, Sîn-ab-ușur, and Nusku-killanni, sons of Nusku-gabbē, hire their slave Šer-idri to perform royal service (palāh šarri). In the Murašu archive, this term is related to obligations in the land-for-service sector. ${ }^{1238}$ It is therefore likely that the family of Nusku-gabbe held a bow land or similar property which was burdened with tax and service obligations. ${ }^{1239}$

The strong royal involvement in the barley debts found in the archive, the royal ownership of the cultivated land, the reference to service obligations, and the very existence of the twin town of Neirab indicate that the Neirabians were integrated into the land-for-service sector of Babylonian agriculture. It is conceivable that, like many other deportees, the Neirabians were settled in a newly founded community and provided with state lands to cultivate. Because most creditors of the barley debts are connected to the royal administration, the texts seem to be related to tax payments. It is possible that the

1235 No. 17. According to Tolini's collation $(2015,84 \mathrm{n} .83)$, the text reads l' gàr lugal which Tolini interprets as a scribal mistake for lúdam.gàr lugal. This is a plausible explanation for the difficult reading. The merchant's father has a West Semitic name, which allows us to count him among the several non-Babylonian royal merchants of this period. See Chapter 3 and Tolini 2015, 84 n. 83 .

1236 On the names, see Tolini $2015,71-72,84$ n. 83 .

1237 Cf. Tolini 2015, 83-84.

1238 CAD P, 46-47; Stolper 1985, 61-62; van Driel 2002, 290.

1239 Tolini $(2015,87)$ arrives at the same conclusion. 
sons of Nusku-gabbē simply paid their own taxes or that they were either foremen of the Neirabian community or businessmen engaged in agricultural management. ${ }^{1240}$

\subsubsection{Promissory Notes for Silver}

The promissory notes for barley fit into a certain pattern, but the set of silver debts is more diverse. However, the promissory notes for barley and silver share a common feature: there was no single loan that the Nusku-gabbē family gave to outsiders - they were always debtors, or the loan was given to other members of the Nusku-gabbē or Īn-Nusku families. ${ }^{1241}$ An interesting difference between the promissory notes for barley and silver is their date of issue: all barley loans were given in the reigns of Neriglissar and Nabonidus, whereas the silver loans were given in the reigns of Nabonidus, Cambyses, Nebuchadnezzar IV, and Darius I. Accordingly, the barley loans characterise the earlier phase and silver loans (nos. 1, 7, 13, 14||24, 16, 19-21, 27) the later phase of the archive. ${ }^{1242}$ Most of the silver loans were of modest size (2.25-9.5 shekels), but the last loan (no. 27) from the reign of Darius was considerably larger, at least one mina. The geographical nature of the barley and silver loans also differed: all of the barley loans were issued in the countryside, whereas the silver loans were issued both in the countryside and in two cities, Babylon (no. 1) and Hìt (no. 19).

Four promissory notes for silver, issued in the countryside in the reign of Nabonidus, are likely to stem from the same economic context as the loans of barley. Two of these can be classified as internal loans within the circles of the Nusku-gabbē and İn-Nusku families: no. 7 is a loan of 8.5 shekels from Manniya/Nusku-gabbē to his brother Nusku-killanni, and no. 14||24, preserved in two copies, is a loan of 4 shekels from Nusku-killanni to Sîn-lēeri/Inn-Nusku. The debtor and the creditor of no. 13 are not attested in other documents, but the loan of 6 shekels, the remainder of the price of a donkey, is guaranteed by Nuhsāya/Nusku-gabbē. Text no. 16 is a promissory note for a modest sum of 2.25 shekels owed by Nusku-killanni to a certain Zabadu/Edu-ana-ummišu. Like in the promissory notes for barley, the dates of issue and repayment are clustered at the turn of the Babylonian year (except for no. 7).

\footnotetext{
1240 Compare to the community of Bīt-Gērāya in the Murašû archive (Section 5.2) and to Ahīqam in Yāhūdu (Section 4.3.6.3).

1241 Fales 1973, 140-141.

1242 For an overview of promissory notes for silver, see Tolini 2015, 78-79.
} 
Two promissory notes for silver (nos. 20 and 27) do not refer to the Nuskugabbē family at all, ${ }^{1243}$ and no. 21 is too fragmentary to allow any reliable restoration of the names of the creditor (PN/Nusku-[...]) and the debtor (PN/ Nusku-[...]). However, nos. 21 and 27 can be connected to the archive via Nusku-na'id/Sîn-lē’i of the İn-Nusku family, who appears as a witness in both documents. All three promissory notes were issued in the Persian period, but the place of writing is illegible on every one of them. On the basis of the Nusku names in nos. 21 and 27, these two transactions took place within the Neirabian community. It is noteworthy that no. 27 concerns a debt that is significantly larger than others, at least one mina. The debts were issued and to be paid back at the turn of the year.

Two debts owed by Nusku-iddin/Nusku-killanni did not originate in the countryside but in the cities of Hìt and Babylon (nos. 19 and 1, respectively). No. 19 is a promissory note for 9.5 shekels of silver, the price of a donkey (1 Camb). Nusku-iddin bought the pack animal in Hit, a city which was located to the north of Babylonia but important for Babylonia because of its bitumen industry. ${ }^{1244}$ Corvée work in Hìt could have forced Nusku-iddin to travel north, ${ }^{1245}$ but the purchase of a pack animal suggests that the journey was connected to trade; of course, labour service and trading activities could take place during the same trip. In any case, it is evident that Nusku-iddin was not the only Neirabian in Hit: the debt was to be paid back in Neirab; the first witness of the document, Nargia/Hananaia, is attested in other texts of the archive; and the name of the second witness, Ilteri-nūr/Nusku-rapē, betrays his Neirabian background.

Another promissory note that was written further away from Neirab is no. 1, issued in Babylon during the short reign of Nebuchadnezzar Iv. Nusku-iddin/ Nusku-killanni owed 6.25 shekels of silver to Šamaš-udammiq/Nusku-māttukkin, but the badly damaged document does not supply any further information. The Nusku name of the creditor suggests that this transaction also took place within the Neirabian community. The background of the debt is probably similar to no. 19, and business activities drove Nusku-iddin to travel to Babylon.

The concentration of silver debts in the later phase of the archive, transition from barley to silver loans, and the archive's wider geographical scope in the Persian period leads Tolini to perceive a greater freedom for the Neirabians at

1243 No. 20 can perhaps be connected with no. 22 via a certain Barīkia. See Fales 1973, 138.

1244 Jursa 2010a, 145-148; Zadok 2014c; Tolini 2015, 88 + n. 89 .

1245 Tolini 2015, 87-88. 
this time. ${ }^{1246}$ This may be true, but, as Tolini notes, these developments may also indicate a change in the business activities of the Nusku-gabbe family. ${ }^{1247}$ It is noteworthy that the change of generation coincides with the widening of the archive's geographical scope, and Nusku-iddin, the grandson of Nuskugabbē, is for the first time attested as a fully independent actor in the promissory notes written in Hìt and Babylon. As several Babylonian archives testify, a change of generation sometimes resulted in changes in economic activities as well. ${ }^{1248}$

The previous discussion shows that - unlike the promissory notes for barley the silver debts do not easily fit a single pattern. The promissory notes for silver from the reign of Nabonidus originate from the countryside, and most of the debtors and creditors belong to the Neirabian community. No links to the royal administration can be observed. According to Tolini, these short-term debts of silver were social loans that helped the Neirabian community to survive during the time of shortage before the new harvest. ${ }^{1249}$ While this might be the case, the documents can also be related to business: ${ }^{1250}$ no. 13, a promissory note for 6 shekels of silver, results from the purchase of a donkey, a pack animal. Three promissory notes from the Persian period do not refer to the descendants of Nusku-gabbē, but two of them pertain to people with typically Neirabian names and can be connected to the rest of the archive via the İn-Nusku family. Finally, two promissory notes indicate a change in the last phase of the archive and Nusku-iddin's presence in the cities of Hìt and Babylon. These documents seem to relate to business activities. The structural difference between the promissory notes for barley and silver apply to the archive as a whole: the earlier tablets from the Neo-Babylonian period are a more coherent group and directly connected to the Nusku-gabbēs, whereas documents from the Persian period are more diverse and sometimes cannot be connected to other documents at all.

\subsubsection{Diverse Documents}

The rest of the documents in the archive are more difficult to put in a larger context, because they are all severely mutilated, otherwise difficult to understand, or do not exhibit links to any other documents of the archive. Nos. 11 and 12 are promissory notes for some unidentified commodity (to be read as ra-su-nu

\footnotetext{
1246 Tolini 2015, 87-90.

1247 Tolini 2015, 89-90.

1248 This is clearly visible in the Egibi archive. See Wunsch 200ob, 2007. See also the texts pertaining to Ahīqam and his sons in Yāhūdu (Section 4.3.6.3).

1249 Tolini 2015, 82.

$125^{\circ}$ See Fales 1973, 137-142.
} 
or ri-sa-nu?) and they are closely linked to each other. They were both issued in the seventh month of the tenth year of Nabonidus, two days between one another, and between the same creditor and debtor, Nargia/Hananaia and Nuhsāya/Nusku-gabbē. They were both written by the scribe Mukīn-apli/ Nādin in Bìt-dayyān-Adad (no. 11) and Ammat (no. 12). The loans were issued in an agricultural context between friends, relatives, or business partners, because Nargia and his son Hidirāya are attested several times in the archive.

No. 2 is a mutilated sale of some property worth 1 mina and 10 shekels of silver. The seller was Nuhsāya/Nusku-gabbē, but the part of the tablet containing the name of the buyer and the place of issue has broken off. The tablet was probably written in the reign of Nebuchadnezzar IV. It indicates - like no. 27 that the size of silver transactions grew in the last phase of the archive.

Two miscellaneous documents do not exhibit links to the Nusku-gabbē or Īn-Nusku families or to Nargia/Hananaia. No. 22 is a sale of a slave in the reign of Cambyses. The seller Barikia may be identical with the co-debtor of no. 20, but the broken sales contract does not allow us to extract any further information. Even less can be said about no. 25: the broken personal names cannot be connected to any other document.

No. 23 (= BMA 11) is a marriage agreement between the groom Bar-ahhāya/ Kukizza and the bride Bazīti's brother Nabû-êtir/Ea-zēr-iddin. The names of the bride, her brother, and her father were all Akkadian, ${ }^{1251}$ but the groom bore a West Semitic name and patronymic. ${ }^{1252}$ As the operative part breaks after introducing the parties of the agreement, nothing can be said about the conditions of the marriage. It is noteworthy that none of the parties bore Sin or Nusku names typical of the Neirabian community, and none of the protagonists or witnesses are attested in other documents. This situation is reminiscent of the marriage agreement from Yāhūdu $(\mathrm{Al}) \cdot{ }^{1253}$ It is possible that the document found its way to the Neirab corpus via a later marriage. ${ }^{254}$

The last document to be discussed is no. 26 , a property document, perhaps a sale, referring several times to Sîn of Neirab. The subject of the transaction is connected to Sîn of Neirab, but the nature of this object will remain obscure until the tablet is collated in the Aleppo museum. However, the reference to Sîn of Neirab seems to imply that the cult of the Neirabian moon god survived among the exiles in Babylonia.

$125^{1}$ On the female name Bazīti, see Cousin and Watai 2016, 10-11.

$125^{2}$ Tolini 2015, 71.

1253 See Section 4.3.6.2.

1254 Cf. Tolini 2015, 91 n. 96. 
The village of Neirab and its inhabitants can be located in the land-for-service sector of Babylonian agriculture. The strong royal presence in the promissory notes for barley, the reference to royal service (paläh šarri), the multi-layered administrative structures, and the archive's origin in the countryside point towards this conclusion. The texts from the village are centred on the descendants of Nusku-gabbē, suggesting that they belonged to their archive. The reference to the service obligations of this family indicates that they held a plot of royal land and were obliged to pay taxes and perform work or military service. The promissory notes for barley were most likely related to tax payments, because the majority of these documents pertain to the royal administration. Except for no. 18, all promissory notes for barley are owed by the sons of Nuskugabbē, and it is possible that these documents simply relate to the tax payments by the family.

There are, however, some features which suggest that the descendants of Nusku-gabbē participated in business activities. First, two sales of a pack animal, a donkey, imply a trading context. Second, Nusku-iddin's travels to Hìt and Babylon and the promissory notes for silver issued in these cities are better explained by commercial activities than tax payments. Third, members of the In-Nusku family are present in several transactions of the archive. They appear most often as witnesses, but no. 18 is a noteworthy exception: Sîn-lēe $\mathrm{i} / \overline{\mathrm{In}}$-Nusku and two members of the Nusku-gabbē family owe a sūtu rent together. This document implies that the three men were involved in agricultural management and that the descendants of Nusku-gabbē and Īn-Nusku were business partners.

We may suggest that the Nusku-gabbē family not only cultivated their own plot of land but also engaged in some entrepreneurial activities. Texts from the reigns of Neriglissar and Nabonidus document their activities in the land-for-service sector: they organised the cultivation of royal properties in the environs of Neirab together with the İn-Nusku family. The sale of a donkey, guaranteed by Nuhsāya/Nusku-gabbē, suggests that the family participated in trading activities already at that time. In the last phase of the archive, the activities of Nusku-iddin/Nusku-killanni extended beyond Neirab and the surrounding villages, and beyond agricultural management in the landfor-service sector. He traded in Hìt and Babylon, but the nature of his transactions remains elusive. The family did not work alone, for the İn-Nusku family and Nargia/Hananaia and his son Hidirāya were also involved in several transactions. 
The majority of texts from Neirab can easily be assigned to the business archive of the descendants of Nusku-gabbē. ${ }^{1255}$ However, there are a number of documents which are not related to the family or its business partners. This may result from return migration: when part of the Neirabians returned from Babylonia to their ancestral hometown, some of them brought a number of cuneiform tablets along. Some originally independent documents got mixed up with the texts of the Nusku-gabbē family, and when one of the returnees died in Neirab of Syria, the tablets were buried together with him.

The texts from Neirab pertain to the same social and economic context as the majority of the documents relating to Judeans. Texts from Neirab, Yāhūdu, and the Murašû archive show that the Babylonian state resettled deportees in communities according to their ethnic origin. This is reflected in the names of the new settlements: Neirab was also known as the town of Neirabians and Yāhūdu as the town of Judeans. The deportees were given a plot of land to cultivate, and they were obliged to pay taxes and perform work and military service in exchange. Accordingly, the deportees were a source of revenue and they were closely supervised. The royal administration is strongly present in all the three text corpora.

It is noteworthy that the texts from Neirab and from the environs of Yāhūdu were written in Babylonian cuneiform. The deportees themselves were hardly literate in Akkadian, but some of them could probably read and write Aramaic or Hebrew. The evidence from the environs of Yāhūdu suggests that the state administration played a central role in the production of the texts, apparently in order to control the activities in the land-for-service sector. The state required that documents were written in cuneiform; this is the reason why transactions between the members of the Neirabian community were written in cuneiform as well. Five documents from Neirab bear Aramaic epigraphs, and such epigraphs are common in the texts from the environs of Yāhūdu and the Murašu archive as well. The existence of the epigraphs suggests that Aramaic was widely used, but that it was necessary to record the transactions primarily in cuneiform.

The naming practices of the Neirabian community exhibit continuity. Names containing the theophoric elements Nusku and Sîn are common in the archive, as are other West Semitic names. The scribes were by far the largest group of people bearing fully Babylonian names, but the influence of Babylonian can be detected in the Neirabian onomasticon as well. Some members of the community had pure West Semitic names, while others used Babylonian

1255 Fales 1973, 137-142. 
names referring to the lunar cult. The persistence of Sîn and Nusku names is reminiscent of the continuity of Yahwistic names among Judean communities in the countryside. It appears that the Babylonian practice of settling deportees in ethnically homogenous villages in the countryside supported cultural continuity among the immigrant communities. 